\title{
Coherent multi-variable field data set of an intensive cropping system for agro-ecosystem modelling from Müncheberg, Germany
}

\author{
Wilfried Mirsche $\left.\right|^{1 *}$, Dietmar Barkusky² ${ }^{2}$, Johannes Hufnage ${ }^{3}$, Kurt Christian Kersebaum ${ }^{1}$, Claas \\ Nendel ${ }^{1}$, Liane Laacke ${ }^{4}$, Karin Luzi ${ }^{1}$, Gunhild Rosner ${ }^{3}$ \\ ${ }^{1}$ Leibniz Centre for Agricultural Landscape Research (ZALF), Institute of Landscape Systems \\ Analysis, Eberswalder Str. 84, 15374 Müncheberg, Germany, wmirschel@zalf.de, \\ 2Leibniz Centre for Agricultural Landscape Research (ZALF), Research Station, Eberswalder Str. 84, \\ 15374 Müncheberg, Germany, \\ ${ }^{3}$ Leibniz Centre for Agricultural Landscape Research (ZALF), Institute of Land Use Systems, \\ Eberswalder Str. 84, 15374 Müncheberg, Germany, \\ ${ }^{4}$ Leibniz Centre for Agricultural Landscape Research (ZALF), Department of Landscape Information \\ Systems, Eberswalder Str. 84, 15374 Müncheberg, Germany. \\ * email: wmirschel@zalf.de
}

\begin{abstract}
A six-year (1993-1998) multivariable data-set for a four-plot intensive crop rotation (sugar beet - winter wheat - winter barley - winter rye - catch crop) located at the Leibniz Centre for Agricultural Landscape Research (ZALF) Experimental Station, Müncheberg, Germany, is documented in detail. The experiment targets crop response to water supply on sandy soils (Eutric Cambisol) by applying rain-fed and irrigated treatments. Weather as well as soil and crop processes were intensively monitored and management actions were consistently recorded. The data set contains coherent data for soil (water, nitrogen contents), crop (ontogenesis, plant, tiller and ear numbers, above-ground and root biomasses, yield, carbon and nitrogen content in biomass and their fractions, sugar content in beet), weather (standard meteorological variables) and management (soil tillage, sowing, fertilisation, irrigation, harvest). In addition, observation methods are briefly described. The data set is available via the Open Research Data Portal at ZALF Müncheberg (Mirschel et al. 2014, doi:10.4228/ZALF.1992.271). The data set was used for model intercomparison within the crop modelling part (CropM) of the international FACCE MACSUR project.
\end{abstract}

Keywords: agro-ecosystem modelling, intensive cropping system, crop-soil-weather-management database, field experiment, Müncheberg (Germany)

1 INTRODUCTION: At present, land use and climate changes act continuously on agricultural landscapes. The use of arable land for different cultivars, different crop rotations and different intensities is changing rapidly, driven mainly by economic factors. Process-based agro-ecosystem models are widely applied tools for assessing impacts of changing boundary conditions to agricultural landscapes and for simulating future scenarios. A wide variety of these models exist, such as APSIM (Holzworth et al. 2015), STICS (Brisson et al., 2003), Daisy (Hansen et al., 2001), CROPSYST (Stöckle et al., 2003) and DSSAT (Jones et al., 2003). Such models require a wide base of experimental data for model parameterisation and model evaluation, including soil, crop, weather/climate and management data (Kersebaum et al. 2015). Model comparisons and multiscenario and multi-model simulations were presented on the basis of such data sets (Bassu et al. 2014; Diekkrüger et al. 1995, Kersebaum et al. 2007; Martre et al. 2015; Kollas et al. 2015, Palosuo et al. 2011, Rötter et al., 2012).

The Leibniz Centre for Agricultural Landscape Research (ZALF), Müncheberg, Germany, has a long tradition of developing agro-ecosystem models, including models such as AGROSIM (Mirschel and Wenkel, 2007), HERMES (Kersebaum, 2011) and MONICA (Nendel et al., 2011). It is impossible to perform scenario simulations for arable land without well-parameterised agro-ecosystem models; in turn, good model parameterisation is only possible on the basis of coherent data sets generated from well-designed field or climate chamber experiments. To support its modelling activities, ZALF Experimental Station started an experiment involving an intensive measurement programme in 1992, which is monitored continuously to the present day. The experiment is carried out in four parallel plots with a shift of one year, such that each crop is represented each year. The experiment is targeted towards the production of coherent data sets for agro-ecosystem model parameterisation and validation, which also represent different management intensities and inter-annual variations in crop rotations under rain-fed and irrigated conditions. 
The intensive cropping system, which is presented here, is part of the long-term field experiment and was established as a four-plot crop rotation in 1992. The data set includes sugar beet (Beta vulgaris subst. vulgaris), winter wheat (Triticum aestivum L.), winter barley (Hordeum vulgare $L$.) and winter rye (Secale cereale L.) as one-and-a-half full crop rotation cycles from 1992 to 1998. A continuously recording meteorological station was established in the vicinity of the experimental plots. Soil and crop variables were measured at weekly to monthly intervals. During the first half of the experiment, the time intervals for measurements were shorter than during the second half.

The data set has already been used to parameterise and evalidate AGROSIM, an agro-ecosystem model family for winter cereals, sugar beet and catch crops (Mirschel and Wenkel, 2007; Mirschel et al., 2001; Wenkel and Mirschel, 1995) developed at ZALF. The data set is one of five currently being used within a pan-European study (Kollas et al., 2015), a joint activity within the crop modelling part of the European JPI FACCE knowledge hub MACSUR:

https://www.facceipi.com/FACCE-Joint-activities/FACCE-MACSUR.

\section{THE FIELD EXPERIMENT}

2.1 LOCATION AND EXPERIMENTAL DESIGN: The Experimental Station at ZALF Müncheberg is located around $40 \mathrm{~km}$ east of Berlin. The experimental area covers $32,193 \mathrm{~m}^{2}$ (four plots) and is located at $52^{\circ} 515^{\prime} \mathrm{N}$ and $14^{\circ} \mathrm{O} \mathrm{E}$ at an altitude of $62 \mathrm{~m}$. The ground is even, and the soil is sandy (Eutric Cambisol). The ground water table is below $12 \mathrm{~m}$ surface distance; no drainage system is installed.

The climate is characterised by high temperatures during late spring and summer, with frequent earlysummer drought periods, and by cold winters with little snow. For the period from 1981 to 2010, the mean annual air temperature was $9.1^{\circ} \mathrm{C}$; the mean winter and summer temperatures were $0.4^{\circ} \mathrm{C}$ and $17.6^{\circ} \mathrm{C}$, respectively. The mean annual precipitation sum was $553 \mathrm{~mm}$ and the mean winter and summer precipitation sums were $116 \mathrm{~mm}$ and $166 \mathrm{~mm}$, respectively. The average weather dynamics throughout the year is shown in Figure 1 as a mean over a 30-year period (1981-2010).

The whole field experiment has a split-block design with management intensity and irrigation as treatment factors. The management factor is subdivided into an intensive cropping system, with standard tillage and pest management; an organic cropping system, where no mineral fertilisers, agrochemicals or ploughing is used; and an extensive cropping system with reduced tillage and use of agrochemicals. Each cropping system has the same crop rotation: sugar beet - winter wheat - winter barley - winter rye - catch crop. The irrigation factor has two treatments: irrigated and rainfed. The data set described here represents only intensive management with the two irrigation treatments.

The whole field experiment consists of four field trials $(27 \mathrm{~m} \times 294.5 \mathrm{~m}$ each), each of which is subdivided evenly into three cropping system blocks with two sub-plots (21 m x $45 \mathrm{~m}$ each) for the irrigation treatment. All plots were divided by border strips. Each plot had four $3 \mathrm{~m}$ strips where all measurements, including hand harvests, were executed, and two $3 \mathrm{~m}$ strips where the crop was harvested using a combine harvester. In the latter strips, the crop was able to grow undisturbed throughout the vegetation period. Figure 2 shows the experimental design of the intensive cropping system. The meteorological station is located in the southern part of the experimental area.

The measurement frequency ranged from every 10 and 60 minutes for meteorological values to fortnightly, monthly or several times a year for soil and crop measurements. For the data set described here, most of the high-frequency measurements were aggregated to daily values. The sampling intervals for soil and crop data were smaller during the first crop rotation. 


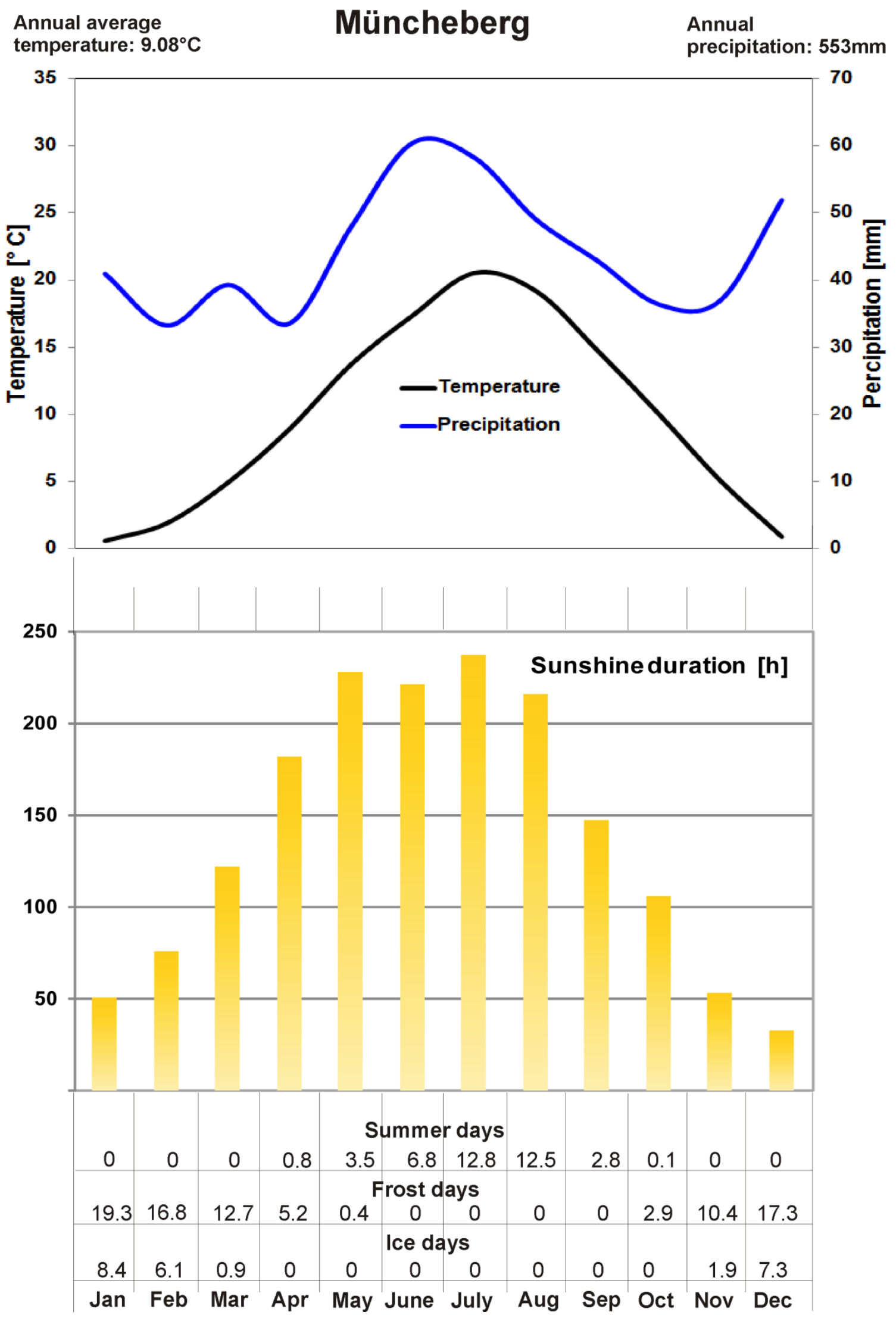

Figure 1. Climatic diagram for Müncheberg meteorological station as a 30-year mean (1981-2010) (summer day: maximum air temperature $>25^{\circ} \mathrm{C}$; frost day: minimum air temperature $<0^{\circ} \mathrm{C}$; ice day: maximum air temperature $<0^{\circ} \mathrm{C}$ ). 
Crop rotation in 1992/1993

winter winter winter sugar

rye barley wheat beet

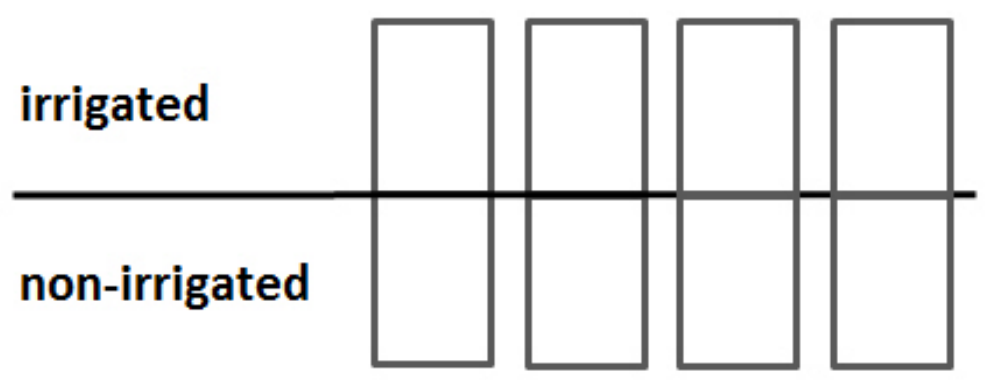

extensive management

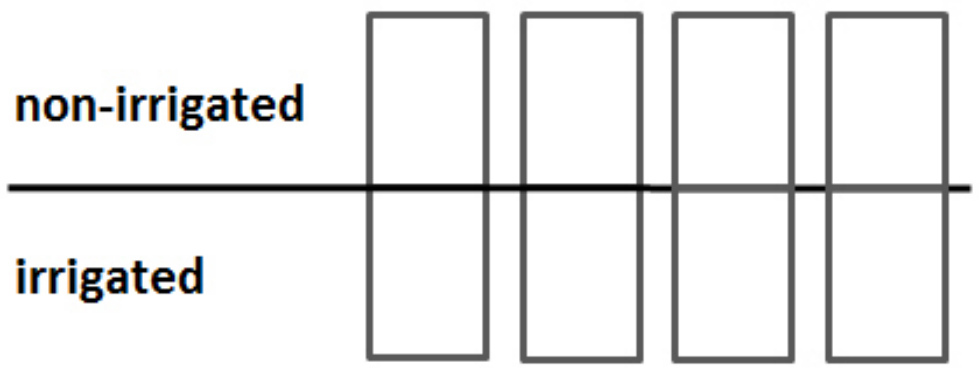

organic management

irrigated

non-irrigated

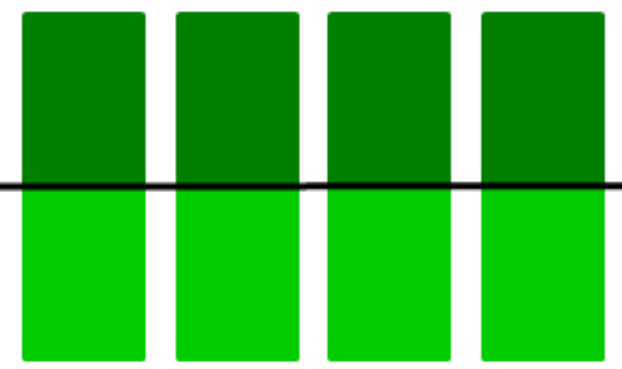

\section{intensive management}

\section{MS}

Figure 2. Experimental design of the whole field experiment containing the intensive cropping system (MS - meteorological station)

2.2 MANAGEMENT: The intensive system is characterised by traditional intensive tillage using the plough; the use of mineral fertiliser (urea ammonium nitrate solution, calcium ammonium nitrate and $P$, $\mathrm{K}$ and $\mathrm{Mg}$ fertilisers) as the primary source of nutrients for the crop and; agrochemicals for intensive pest management. Green manure from catch crops (oil radish) before sugar beet, and straw and leaves as residuals from cereals and sugar beet are the only organic materials considered to maintain soil fertility. The catch crop, the selected cultivars and the seed densities are typical of intensive cropping systems according to common practice.

All management practices for the intensive cropping system which are relevant for agro-ecosystem modelling are shown in Table 1. 


\begin{tabular}{|c|c|c|c|}
\hline Management practice & Unit & Management practice & Unit \\
\hline Crop & - & Irrigation water & $\mathrm{mm}$ \\
\hline Cultivar & - & Date of irrigation & dd.mm.yy \\
\hline Row distance & $\mathrm{cm}$ & Type of soil tillage & - \\
\hline Sowing date & dd.mm.yy & Tillage depth & $\mathrm{cm}$ \\
\hline Germinable seed grains & $\mathrm{m}-2$ & Date of soil tillage & dd.mm.yy \\
\hline Emergence date & dd.mm.yy & Additional information & \\
\hline Harvest date & dd.mm.yy & & \\
\hline Fertiliser type & - & & \\
\hline Amount of fertiliser (N/P/K/Mg) & kg ha-1 & & \\
\hline Date of fertiliser application & dd.mm.yy & & \\
\hline
\end{tabular}

In the given crop rotation, a number of deviations from the original design occurred in 1995 and 1996. Due to very bad over-winter conditions (black frost, snow mould infection) in 1994/1995, the winter wheat crop was ploughed under after winter and spring wheat was sown in March 1995. An analogue procedure was followed in 1995/1996 for winter barley, which was ploughed after winter and spring barley was sown in April 1996.

Additional management information, especially on pest management practices, is given in Wenkel and Mirschel (1995).

\subsection{MEASUREMENTS}

2.3.1 WEATHER DATA: Weather data at the experimental site were collected every ten minutes by an automated micro-meteorological station FMA 86 (type "Weihenstephan", Lambrecht GmbH Göttingen, Germany), which is located $20 \mathrm{~m}$ from the field experiment (Figure 2). FMA 86 also measures soil temperature at different depths. Detailed information about sensors, their range and accuracy are given in Wenkel and Mirschel (1995) and Mirschel et al. (2007). The data collected every 10 minutes was automatically aggregated to hourly and/or daily data sets. No values were entered in the data set for days when the entire meteorological station or single sensors were out of order. The weather data measured is listed in Table 2.

Table 2. Daily weather data at Müncheberg Experimental Station measured by the micrometeorological station FMA 86

\begin{tabular}{lll}
\hline Meteorological variable & Unit & Sampling height/depth $(\mathbf{c m})$ \\
\hline Precipitation & $\mathrm{mm}$ & 100 \\
Mean air temperature & ${ }^{\circ} \mathrm{C}$ & 200 \\
Minimum air temperature & ${ }^{\circ} \mathrm{C}$ & 200 \\
Maximum air temperature & ${ }^{\circ} \mathrm{C}$ & 200 \\
Air temperature at 14:00 & ${ }^{\circ} \mathrm{C}$ & 200 \\
Mean relative air humidity & $\%$ & 200 \\
Relative air humidity at $14: 00$ & $\%$ & 200 \\
Global radiation & $\mathrm{J} \mathrm{cm}^{-2}$ & 200 \\
Mean wind speed & $\mathrm{m} \mathrm{s}^{-1}$ & 250 \\
Mean soil temperature & ${ }^{\circ} \mathrm{C}$ & 5 \\
Mean soil temperature & ${ }^{\circ} \mathrm{C}$ & 20 \\
Mean soil temperature & ${ }^{\circ} \mathrm{C}$ & 50 \\
\hline
\end{tabular}

2.3.2 SOIL DATA: Manual methods were used to sample soil values; automatic methods were applied to sample soil temperature. In order to analyse the soil water and soil nitrogen contents in the laboratory, randomised soil samples were taken from three different soil layers $(0-30 \mathrm{~cm}, 30-60 \mathrm{~cm}$ and $60-90 \mathrm{~cm}$ ) in replicates using an auger as the basis for a mixed sample for each field plot.

2.3.2.1 PROFILE DESCRIPTION: The chemical and physical properties for the soil profile to a depth of $200 \mathrm{~cm}$ are given in Table 3. All four plots of the intensive cropping system have similar soil properties. It was not possible to determine a number of properties for the deeper horizons. No significant differences among the four plots were observed for organic carbon, total nitrogen, bulk density and $\mathrm{pH}$. Additional information on soil characteristics and soil profiles for ZALF Experimental Station is provided in Schindler (1980). 
Table 3. Soil properties measured at intensive cropping system plots (taken from Mirschel et al., 2007)

\begin{tabular}{llllllllll}
\hline $\begin{array}{l}\text { Horizon Depth } \\
\text { (cm) }\end{array}$ & $\begin{array}{l}\text { Sand } \\
\text { (\%) }\end{array}$ & $\begin{array}{l}\text { Silt } \\
\text { (\%) }\end{array}$ & $\begin{array}{l}\text { Clay } \\
\text { (\%) }\end{array}$ & $\begin{array}{l}\text { Organic } \\
\text { carbon } \\
\text { (\%) }\end{array}$ & $\begin{array}{l}\text { Total } \\
\text { nitrogen } \\
\text { (\%) }\end{array}$ & C:N & pH & $\begin{array}{l}\text { Bulk } \\
\text { density } \\
\text { (g cm }\end{array}$ \\
\hline $\mathrm{Ap}$ & $0-30$ & 83 & 9 & 8 & 0.66 & 0.054 & 12.1 & 6.1 & 1.45 \\
$\mathrm{Ael}$ & $30-60$ & 86 & 8 & 6 & 0.16 & 0.015 & 11.0 & 6.1 & 1.50 \\
$\mathrm{Bt}$ & $60-90$ & 72 & 14 & 14 & 0.08 & 0.007 & 11.1 & 6.3 & 1.55 \\
$\mathrm{C} 1$ & $90-110$ & 83 & 10 & 7 & n.a. & n.a. & n.a. & n.a. & n.a. \\
$\mathrm{C} 2$ & $110-160$ & 92 & 7 & 1 & n.a. & n.a. & n.a. & n.a. & n.a. \\
$\mathrm{C} 3$ & $160-210$ & 98 & 1 & 1 & n.a. & n.a. & n.a. & n.a. & n.a. \\
\hline
\end{tabular}

n.a. - not available

2.3.2.2 SOIL WATER, SOIL NITROGEN AND SOIL TEMPERATURE: Soil water content was determined gravimetrically by difference weighing before and after oven drying at a temperature of $105^{\circ} \mathrm{C}$. Using bulk density soil water content was converted into Vol\%. The bulk sensity was measured using a metal ring with a known volume and determining the weight after drying. Soil sampling for determining soil mineral nitrogen and soil water content was carried out in accordance with the " $\mathrm{N}_{\min }$ Method" (Wehrmann and Scharpf, 1979). Mixed samples were formed from 12 to 14 auger samples. The samples were taken using a "Pürkhauer" half-cylindrical soil auger that was rammed into the soil down to a depth of $90 \mathrm{~cm}$. The mixed samples were transported in a cold box and analysed the same day. Soil was extracted using $\mathrm{KCl}$ solution (Mirschel et al., 2007).

Soil temperatures were measured every 10 minutes using "PT100" epoxy-embedded thermistors with an accuracy of $0.2 \mathrm{~K}$. They were then aggregated to mean daily soil temperature values (see Table 2). For depths at $5 \mathrm{~cm}, 20 \mathrm{~cm}$ and $50 \mathrm{~cm}$, the thermistors were located $2.5 \mathrm{~m}$ from the micrometeorological station under grass cover, not in the intensively cropped plots.

\subsubsection{CROP DATA}

2.3.3.1 ONTOGENESIS, PLANT CHARACTERISTICS AND BIOMASS: The development stages of all crops within the crop rotation between emergence and maturity were estimated weekly using the BBCH scale (Hack et al., 1992) for cereals and sugar beet, a decimal code system prevalent in Germany, identical to the decimal code system according to Zadoks (1974).

For cereals, the number of plants, tillers and ears were determined on the basis of $1 \mathrm{~m}^{2}$ sections in nine randomised replicates within every plot. For sugar beet, the number of plants was determined based on a $9.6 \mathrm{~m}$ long row section (approximately $4 \mathrm{~m}^{2}$ ) in nine randomised replicates. Finally, a plot average was calculated.

In the sub-areas for manual harvesting, above-ground and root biomasses were determined periodically. In each of the four plots, three randomised replicates for cereals and sugar beets were taken as mixed samples per sampling date from $0.25 \mathrm{~m}^{2}$ sampling sections for cereals and $1 \mathrm{~m}^{2}$ sampling sections (a $2.4 \mathrm{~m}$ long row section) for sugar beet. After combining replicate subsamples, the material harvested was separated into steam/leaves and ears (including grain, glume and rest of the ear) for cereals and into beet and leaves (including petioles) for sugar beet; the fresh biomass was measured. In addition, the root biomass was determined for cereals only. To this end, roots were washed manually from a top $30 \mathrm{~cm}$ soil core. In order to determine dry biomass, $1000 \mathrm{~g}$ fresh biomass subsamples were taken from each biomass fraction sample and oven-dried at around $60^{\circ} \mathrm{C}$ for two to three days.

For sugar beet, the sugar content was measured using an automatic light-electric polarimeter "POLAMAT S" (Riegler and Schiek, 1970; Strube and Scholze, 1970). An overview of the plant characteristics, biomass and ontogenesis values is given in Table 4. 


\begin{tabular}{lll}
\hline \multicolumn{2}{l}{ Table 4. Overview of plant, biomass and ontogenesis values of the intensive cropping system plots } \\
\hline Crop value & Unit & Harvesting form \\
\hline Crop type & - & \\
Ontogenesis stage & $\mathrm{DC}$ & \\
Number of plants & $\mathrm{m}^{-2}$ & \\
Number of tillers & $\mathrm{m}^{-2}$ & \\
Number of ears & $\mathrm{m}^{-2}$ & \\
Above-ground biomass (stems + leaves) (DM) & $\mathrm{kg} \mathrm{ha}^{-1}$ & $\mathrm{H}$ \\
Root biomass (DM) & $\mathrm{kg} \mathrm{ha}^{-1}$ & $\mathrm{H}$ \\
Grain biomass (DM) or beet biomass (DM) & $\mathrm{kg} \mathrm{ha}$ & $\mathrm{H}$ \\
Grain biomass (DM) & $\mathrm{Cg} \mathrm{ha}$ \\
Sugar content & $\%$ & \\
\hline
\end{tabular}

DC - decimal code; DM - dry matter; $\mathrm{H}$ - harvested by hand; $\mathrm{C}$ - harvested by combine

2.3.3.2 CARBON AND NITROGEN IN BIOMASS: In order to determine total plant nitrogen and carbon in the laboratory, the dried plant probes were milled. The Kjeldahl method (Bock, 1972) was used to extract the total plant nitrogen. Nitrogen compounds were analysed using spectro-photometric analysis at $578 \mathrm{~nm}$ (photometer EPOS 5060 produced by Eppendorf). Total plant carbon was determined using elementary analysis. The plant sample was incinerated within an oxygen environment at $1250^{\circ} \mathrm{C}$. After oxidation, the quantity of $\mathrm{CO}_{2}$ gas was measured using the element analyser CNS 2000 (Leco, St. Joseph, MI, USA). An overview of the quantities of plant carbon and nitrogen is given in Table 5 .

Table 5. Overview of the quantities of plant carbon and nitrogen from the intensive cropping system plots.

\begin{tabular}{lll}
\hline Crop value & Unit & Harvesting form \\
\hline Crop type & - & \\
Carbon in above-ground biomass (stem + leaves) & $\mathrm{kg} \mathrm{ha}^{-1}$ & $\mathrm{H}$ \\
Carbon in root biomass & $\mathrm{kg} \mathrm{ha}^{-1}$ & $\mathrm{H}$ \\
Carbon in ear or beet biomass & $\mathrm{kg} \mathrm{ha}^{-1}$ & $\mathrm{H}$ \\
Nitrogen in above-ground biomass (stem + leaves) & $\mathrm{kg} \mathrm{ha}^{-1}$ & $\mathrm{H}$ \\
Nitrogen in root biomass & $\mathrm{kg} \mathrm{ha}^{-1}$ & $\mathrm{H}$ \\
Nitrogen in ear or beet biomass & $\mathrm{kg} \mathrm{ha}^{-1}$ & $\mathrm{H}$ \\
Nitrogen in grain & $\mathrm{kg} \mathrm{ha}^{-1}$ & $\mathrm{C}$ \\
\hline
\end{tabular}

$\mathrm{H}$ - harvested by hand; $\mathrm{C}$ - harvested by combine

3 DATA SET STRUCTURE AND DATA ACCESS: The open research data-set described above is structured into seven tables. All table names begin with V004, ZALF's internal code for the experiment. Table 6 shows data set tables and their column structure.

The six-year data set is available via the Open Research Data Portal of the Leibniz Centre for Agricultural Landscape Research and is published under doi 10.4228/ZALF.1992.271 (Mirschel et al. 2014). The data tables in the downloaded zip file have a comma-separated values format (CSV). A brief description of the methods used for data acquisition is also shown there; information is also provided about the location of all field plots at ZALF Experimental Station in Müncheberg. 
Table 6. Overview of all data set tables

\begin{tabular}{|c|c|}
\hline Table name: V004 & Content and comments \\
\hline _EXPERIMENT & $\begin{array}{l}\text { Plot number (example:V004M1F1I1), management (M) type } \\
(1-\text { intensive cropping system), field }(F) \text { number }(1 \ldots 4) \text {, } \\
\text { irrigation (I) }(1-\text { without, } 2 \text { - with irrigation) }\end{array}$ \\
\hline _MUENCHEBERG_WEATHER_92_98 & $\begin{array}{l}\text { The first table columns are: date (dd.mm.yyyy), year, month, } \\
\text { day, Julian day. For all other columns, see Table } 2 \text {. }\end{array}$ \\
\hline _SOIL_PLOT & $\begin{array}{l}\text { After the plot number, all necessary soil properties } \\
\text { measured in the intensive cropping system are listed (see } \\
\text { Table 3). The plot name V004M1 also refers to all other } \\
\text { intensively managed fields. }\end{array}$ \\
\hline _MANAGEMENT & $\begin{array}{l}\text { The management information is listed after the plot number, } \\
\text { starting with the crop type and the cultivar in the other } \\
\text { columns (see Table 1). }\end{array}$ \\
\hline _SOIL_H2O_NMIN_CONTENT & $\begin{array}{l}\text { The table columns are: plot number, date (dd.mm.yyyy), } \\
\text { year, month, Julian day, soil water } 0-30 \mathrm{~cm} \text {, soil water } 30-60 \\
\mathrm{~cm} \text {, soil water } 60-90 \mathrm{~cm} \text {, soil nitrogen } 0-30 \mathrm{~cm} \text {, soil nitrogen } \\
30-60 \mathrm{~cm} \text {, soil nitrogen } 60-90 \mathrm{~cm} \text {; unit for soil water: Vol\%; } \\
\text { unit for soil nitrogen: } \mathrm{kg} \mathrm{ha}^{-1}\end{array}$ \\
\hline _CROP_ONTOGENESIS_BIOMASS & $\begin{array}{l}\text { The first table columns are: plot number, date (dd.mm.yyyy), } \\
\text { year, month, day, Julian day. For all other columns, see } \\
\text { Table } 4 \text {. }\end{array}$ \\
\hline _CROP_CARBON_NITROGEN & $\begin{array}{l}\text { The first table columns are: plot number, date (dd.mm.yyyy), } \\
\text { year, month, day, Julian day. For the other columns, see } \\
\text { Table } 5 \text {. The last column is the harvest method (H - by } \\
\text { hand, } C \text { - by combine) }\end{array}$ \\
\hline
\end{tabular}

4 ACKNOWLEDGEMENTS: The authors are grateful to M. Bähr, E. Klank, S. Dittmar, P. Eisermann, G. Bähr and F. Reining, as representatives of all those involved in the sampling and measuring processes. We would also like to thank our colleagues at ZALF Experimental Station for conducting the field experiments. We are also grateful to R. Schmitt and J. Pilz from ZALF's Landscape Information System group for the useful assistance they gave in preparing this data set for the open research data portal. Last but not least, the authors would like to acknowledge the support received from the German Federal Ministry of Food and Agriculture, the German Federal Ministry of Education and Research and the Brandenburg Ministry of Sciences, Research and Cultural Affairs.

\section{REFERENCES}

Bassu, S., Brisson, N., Durand, J.-L., Boote, K., Lizaso, J., Jones, J.W., Rosenzweig, C., Ruane, A.C., Adam, M., Baron, C., Basso, B., Biernath, C., Boogaard, H., Conijn, S., Corbeels, M., Deryng, D., De Sanctis, G., Gayler, S., Grassini, P., Hatfield, J., Hoek, S., Izaurralde, C., Jongschaap, R., Kemanian, A.R., Kersebaum, K.C., Kim, S.H., Kumar, N.S., Makowski, D., Müller, C., Nendel, C., Priesack, E., Pravia, M.V., Sau, F., Shcherbak, I., Tao, F., Teixeira, E., Timlin, D., Waha, K. 2014: "How do various maize crop models vary in their responses to climate change factors?" Global Change Biology, 20, No. 7, 2301-2320, http://dx.doi.org/10.1111/gcb.12520.

Bock, R. 1972. "Aufschlussmethoden der anorganischen und organischen Chemie." Verlag Chemie, Weinheimpp. $232 \mathrm{pp}$.

Brisson, N., Gary, C., Justes, E., Roche, R., Mary, B., Ripoche, D., Zimmer, D., Sierra, J., Bertuzzi, P., Burger, P., Bussiere, F., Cabidoche, Y.M., Cellier, P., Debaeke, P., Gaudillere, J.P., Henault, C., Maraux, F., Seguin, B., Sinoquet, H. 2003. "An overview of the crop model STICS." European Journal of Agronomy, 18(3): 309-332.

Diekkrüger, B., Söndgerath, D., Kersebaum, K.C., McVoy, C.W. 1995. "Validity of agroecosystem models - A comparison of results of different models applied to the same data set." Ecological Modelling 81(1-3): 3-29.

Hack H., Bleiholder H., Buhr L., Meier U. Schnock-Fricke U., Weber E.,Witzenberger A. 1992. "Einheitliche Codierung der phänologischen Entwicklungsstadien mono- und dikotyler Pflanzen - Erweiterte BBCH-Skala." Allgemein.- Nachrichtenblad Deutsche Pflanzenschutzdienst 44: 265-270. 
Hansen, S., Thirup, C., Refsgaard, J. and Jensen, L. 2001. "Modelling nitrate leaching at different scales-application of the Daisy model." Modeling Carbon and Nitrogen Dynamics for Soil Management. CRC Press, Boca Raton, FL: 511-547.

Holzworth, D.P., Snow, V., Janssen, S., Athanasiadis, I.N., Donatelli, M., Hoogenboom, G., White, J.W., Thorburn, P. 2015. "Agricultural production systems modelling and software: Current status and future prospects." Environmental Modelling \& Software 72: 276-289, http://dx.doi.org/10.1016/j.envsoft.2014.12.013.

Jones, J.W. et al. 2003. "The DSSAT cropping system model." European Journal of Agronomy, 18(3): 235-265.

Kersebaum, K. 2011. "Special features of the HERMES model and additional procedures for parameterization, calibration, validation, and applications." Methods of Introducing System Models into Agricultural Research: 65-94.

Kersebaum, K.-C., Boote, K., Jorgenson, J., Kollas, C., Nendel, C., Wegehenkel, M., Bindi, M., Oelsen, J., Frühauf, C., Gaiser, T., Ruget, F., Rötter, R., Trnka, M. 2014. "A scheme to evaluate suitability of experimental data for model testing and improvement." CropM International Symposium and Workshop: Modelling climate change impacts on crop production for food security, 10-12 February 2014, Oslo, Norway; Abstract Book. p. 31.

Kersebaum,K.C., Hecker, J.-M., Mirschel, W., Wegehenkel, M. (eds.) 2007. "Modelling Water and Nutrient Dynamics in Soil-Crop Systems: proceedings of the workshop on "Modelling water and nutrient dynamics in soil-crop systems" held on 14-16 June 2004 in Müncheberg, Germany." 271 p., Dordrecht (Springer).

Kollas, C., Kersebaum, K.C., Nendel, C., Manevski, K., Müller, C., Palosuo, T., Armas-Herrera, C.M., Beaudoin, N., Bindi, M., Charfeddine, M., Conradt, T., Constantin, J., Eitzinger, J., Ewert, F., Ferrise, R., Gaiser, T., de Cortazar-Atauri, I.G., Giglio, L., Hlavinka, P., Hoffmann, H., Hoffmann, M.P., Launay, M., Manderscheid, R., Mary, B., Mirschel, W., Moriondo, M., Olesen, J., Öztürk, I., Pacholsky, A., Ripoche-Wachter, D., Roggero, P.P., Roncossek, S., Rötter, R., Ruget, F., Sharif, B., Trnka, M., Ventrella, D., Waha, K., Wegehenkel, M., Weigel, H.-J., Wu, L. 2015. "Crop rotation modelling - a European model intercomparison." European Journal of Agronomy 70: 98-111.

Martre, P., Wallach, D., Asseng, S., Ewert, F., Jones, J. W., Rötter, R. P., Boote, K. J., Ruane, A. C., Thorburn, P. J., Cammarano, D., Hatfield, J. L., Rosenzweig, C., Aggarwal, P. k., Angulo, C., Basso, B., Bertuzzi, P., Biernath, C., Brisson, N., Challinor, A. J., Doltra, J., Gayler, S., Goldberg, R., Grant, R. F., Heng, L., Hooker, J., Hunt, L. A., Ingwersen, J., Izaurralde, R. C., Kersebaum, K.-C., Müller, C., Kumar, S. N., Nendel, C., O'Leary, G., Olesen, J. E., Osborne, T. M., Palosuo, T., Priesack, E., Ripoche, D., Semenov, M. A., Shcherbak, I., Steduto, P., Stöckle, C. O., Stratonovitch, P., Streck, T., Supit, I., Tao, F., Travasso, M., Waha, K., White, J. W., Wolf, J. 2015. "Multimodel ensembles of wheat growth: many models are better than one." Global Change Biology 21(2), 911:925.

Mirschel, W., Schindler, U., Hufnagel, J., Barkusky, D., Dittmar, S., Voigt, C., Laacke, L. 2014. "Coherent multivariable 6-year field trial data set for agro-ecosystem model verification and validation from Müncheberg experimental station." Leibniz-Zentrum für Agrarlandschaftsforschung (ZALF) e.V., http://dx.doi.org/10.4228/ZALF.1992.271.

Mirschel, W.; Schultz, A.; Wenkel, K.-O. 2001. "Assessing the Impact of Land Use Intensity and Climate Change on Ontogenesis, Biomass Production, and Yield of Northeast German Agrolandscapes." In: Tenhunen, J.D.; Lenz, R.; Hantschel (eds.): Ecosystem Approaches to Landscape Management in Central Europe. Ecological Studies, Vol. 147, Springer-Verlag Berlin Heidelberg, New York, 2001, p. 299-313.

Mirschel, W., Wenkel, K.-O. 2007. "Modelling soil-crop interactions with AGROSIM model family." In: Kersebaum, K.C.; Hecker, J.-M.; Mirschel, W.; Wegehenkel, M. (eds.): Modelling Water and Nutrient Dynamics in Soil-Crop Systems: proceedings of the workshop on "Modelling water and nutrient dynamics in soil-crop systems" held on 14-16 June 2004 in Müncheberg, Germany, Dordrecht (Springer), 59:73.

Mirschel, W., Wenkel, K.-O., Wegehenkel, M., Kersebaum K.C., Schindler, U., Hecker, J.-M. 2007. "Müncheberg field trial data set for agro-ecosystem model validation." In: Kersebaum, K.C.; Hecker, J.-M.; Mirschel, W.; Wegehenkel, M. (eds.): Modelling Water and Nutrient Dynamics in Soil-Crop Systems: proceedings of the workshop on "Modelling water and nutrient dynamics in soil-crop systems" held on 14-16 June 2004 in Müncheberg, Germany, Dordrecht (Springer), 219-243.

Nendel, C., Berg, M., Kersebaum, K.-C., Mirschel, W., Specka, X., Wegehenkel, M., Wenkel, K.-O., Wieland, R. 2011. "The MONICA model: Testing predictability for crop growth, soil moisture and nitrogen dynamics." Ecological Modelling 222(9): 1614-1625. 
Palosuo, T., Kersebaum, K.-C., Angulo, C., Hlavinka, P., Moriondo, M., Olesen, J. E., Patil, R. H., Ruget, F., Rumbaur, C., Takac, J., Trnka, M., Bindi, M., Caldag, B., Ewert, F., Ferrise, R., Mirschel, W., Saylan, L., Siska, B., Rötter, R. 2011. "Simulation of winter wheat yield and its variability in different climates of Europe: a comparison of eight crop growth models." European Journal of Agronomy 35, 3, 103-114.

Riegler H., Schiek O. 1970. "Automatisches Polarimeter für die Zuckerindustrie." LebensmittelIndustrie 1970(11): 1-2.

Rötter, R. P., Palosuo, T., Kersebaum, K.-C., Angulo, C., Bindi, M., Ewert, F., Ferrise, R., Hlavinka, P., Moriondo, M., Nendel, C., Olesen, J. E., Patil, R. H., Ruget, F., Takác, J., Trnka, M. 2012. "Simulation of spring barley yield in different climatic zones of Northern and Central Europe: a comparison of nine crop models." Field Crops Research 133, 23-36.

Schindler, U. 1980. "Ein Schnellverfahren zur Messung der Wasserleitfähigkeit im teilgesättigten Boden an Stechzylinderproben." Arch. Acker-, Pflanzenbau und Bodenkunde 24: 1-7.

Stöckle, C.O., Donatelli, M. and Nelson, R. 2003. "CropSyst, a cropping systems simulation model." European Journal of Agronomy, 18(3): 289-307.

Strube W., Scholze D. 1970. "Erprobung des automatischen Polarimeters POLAMAT S." LebensmittelIndustrie 1970(11): 2-4.

Wehrmann J. and Scharpf H.-C. 1979. "Der Mineralstickstoffgehalt des Bodens als Massstab für den Stickstoffdüngungsbedarf (Nmin-Methode)." Plant and Soil 52: 109-126.

Wenkel, K.-O., Mirschel, W. (eds.) 1995. "Agroökosystemmodellierung - Grundlage für die Abschätzung von Auswirkungen möglicher Landnutzungs- und Klimaänderungen." ZALFBericht, 24: 187 pp.

Zadoks J.C., Chang, T.T., Konzak, C.F. 1974. "A decimal code for growth stages of cereals." Weed Research. 14: 415-421. 